time and the sun was clearly reflected on a distant wet mud flat, no doubt forming an extension of the northward sloping beach, so as to give an image below the level of the observer's eye and to the left of the sun, that is to say, lying in a direction somewhat farther round towards the south. Mr. Evans attributes the third bow to this additional source of light. It appeared as a short are with colours arranged in the same order as those in the primary bow, with an apparent centre of curvature above the horizon and north of the centre of curvature of the two ordinary bows. He estimated that about two-thirds of a complete circle would have been above the horizon had the arc continued far enough, while the two normal bows would have shown to only half that extent above the horizon. The explanation offered seems to accord well with the observed effect.

\section{Distributive Enterprises in the United States}

IN the United States decennial census of population for 1930 , there was included, for the first time in any country, a special census of distributive enterprises and activities. In order to bring this important innovation to the attention of business men, traders and others, a report has been prepared for the International Distribution Commission by the International Management Institute (2, Boulevard du Théatre, Geneva, pp. 72 ; 2 Swiss francs). This report points out that the American experiment in the statistical study of a hitherto neglected aspect of economic activity is likely to prove extremely valuable to other countries. The distribution census provides a complete guide to the position in the United States in 1930 with regard to distributive enterprises throughout the country, including particulars of their size, turnover, expenditure, number of employees, type of organisation and similar facts. The census of distribution is complementary to a census of production since it is an attempt to establish the exact statistical facts as to the various enterprises engaged in distributive as opposed to productive activities. The material provided should be of particular value to small retailers since they will obtain facts and information which larger concerns have in the past gathered for themselves at considerable expense. The census provides a unique contribution towards the study of an important aspect of economic organisation. Greater distributive efficiency would increase the power of the market to absorb goods and services, whereas at present, production is limited to the capacity of ill-organised markets.

\footnotetext{
Aiming at $I, 000$ kilovolts for the Transmission of Power AN account by Mr. T. Rich of a recent High Tension Congress at Paris is given in the Electrician beginning on July 28. The problems of the use of direct current for power transmission and the many uses of thermionic converters were discussed in several papers. M. Sitnikov, of Leningrad, described a system of thermionic converters with cold electrodes and magnetic control which possesses many advantages for the transmission of power by direct current.
}

Experiments prove that, for a discharge in gas, the limit of the current which can be passed by the tube is determined by the limiting value of the power which can be given out by the two cold electrodes at a sufficiently low temperature so that their surfaces suffer no deterioration. The gaseous column will carry practically any current, provided the energy can be taken from the electrodes. A tube tested up to 70 kilovolts operated quite satisfactorily up to 30 kilovolts. A plan is under consideration in Russia for the transport of a million kilowatts at a pressure of the order of 600 kilovolts. The necessary researches in connexion with the converter tubes are being carried out in Leningrad. Mr. E. S. Henriksen, of the Norwegian Nitrogen Co., described the development of valves with grid control for very high tensions. He stated that if 400 kilovolts is the highest voltage practical with three phase current, then with direct current 725 kilovolts is possible with overhead transmission and 1,000 kilovolts with underground cables. Various schemes were discussed relating to a project for transporting power from Norway to the north of France. It will be remembered that the voltage of the English 'grid' is 132 kilovolts.

\section{An Industrial Jubilee in Sweden}

In the Asea Journal (Allmanna Svenska Elektriska) for April there is an interesting account of the jubilee of the Asea Electric Co., which was founded fifty years ago. In 1883 , it employed seven workmen and the total horse power of all the machines manufactured was 62. For the ten years before the War, the development of hydro-electric supply systems in Sweden created a great demand for electric machinery. During the War, thanks to the neutrality of Sweden, the business rapidly increased. The scarcity of petrol also gave a great impulse to the use of electrical energy and networks of wires were erected over various parts of the country. For the last ten years new forms of rationalisation have been introduced into the various branches of the business, and last year it employed 10,000 workmen and the horse power of the machines manufactured reached a total of one and a half million. The celebrations were initiated by a special performance at the Royal Opera House in Stockholm to which all its employees were invited. In Sweden it is the custom for the Royal Patriotic Society to present long-service medals to persons industrially employed as a token of recognition for faithful and loyal service. Two hundred and forty-four of the company's workmen and engineers were presented with the 30 years' medal. At the conclusion of the ceremonies the directors gave donations amounting to $£ 40,000$.

\section{Eighteenth Century Map of Hampshire}

WE have received from the Hampshire Field Club and Archæological Society a copy of the reproduction, on a slightly reduced scale, of the map of Hampshire by Isaac Taylor, 1759, which has recently been published by the Society (Winchester : price to nonmembers $6 s$. net). The scale of the original map is one inch to the mile, the reproduction being threequarters of an inch to the mile. The map is a beautiful 
production in characteristic eighteenth century style, with engravings of buildings such as Porchester Castle and "Carresbrook Castle" as well as a plan of Silchester, lists of "Gentlemen's Names", etc. It is interesting to note that exaggerated emphasis is given to relief. Very little appears to be known of Isaac Taylor. He was a native of Ross in Herefordshire. His first-known map is a Plan of Oxfordshire, issued in 1750 and his last a map of the county of Gloucester, which appeared in 1777. He was both an engraver and a surveyor, and on the map of Hampshire there is a note "Estates are surveyed and mapped". His more important maps, in addition to those named, are Wolverhampton, 1750, County of Hereford, 1754, Hereford City, 1757, Dorset, 1765, County of Worcester, 1772.

\section{Revision of Ordnance Plans}

A LEAFLET on the revision of areas of twenty-five inch plans, issued by the Ordnance Survey, notes that revision is far behind the standard formerly uchieved. The hiatus due to the War meant a gap that would not have been easy to bridge even if other difficulties had not supervened. Road and housing development have led to abnormally quick changes within the last twelve years. But most serious of all has been the effect of the call for public economy. Since 1928, revision has, perforce, been limited to those areas in which development and changes have reached a certain standard. This standard is defined as the addition of 200 houses or equivalent area of factory, road or other development in a six-inch quarter sheet. This principle means the abandonment of the revision of any county as a unit, which in former days was done every twenty years. It has much reduced the areas scheduled annually for revision.

\section{Bibliography of Sir James Frazer's Work}

IN January next Sir James Frazer will celebrate his eightieth birthday. In the same year will fall the fiftieth anniversary of the publication of his first work. To meet the desire of his many friends and admirers, who feel that there should be some appropriate mark of the occasion, which would convey to Sir James the esteem in which he is widely held, it has been decided that a number of learned societies, with which Sir James has been connected, should join under the auspices of the Folk-lore Society in the compilation and publication of a complete bibliography of his writings. It is probable that no form of commemoration could be more appropriate than this. It will serve as a perpetual reminder of the wide range of learning that Sir James has covered in his long life of activity in the service of humane letters and science. The editorship of the volume has been entrusted to Mr. Theodore Besterman, 47 Great Ormond Street, London, W.C.1, to whom subscriptions (10s. 6d.) should be sent.

\section{Distribution of British Animals}

THE significance of the distribution of a species or group of species is often best appreciated by mapplotting. To simplify and encourage this method, an octavo map has been prepared showing the counties and vice-counties of Great Britain as delimited for the Watsonian botanical scheme. The areas are numbered so clearly that no confusion can arise, and the key to the numbers is printed alongside the map. Two series have been prepared; one is printed in black, in the other the county outlines, numbers, and list are printed in blue, so that although perfectly legible in ordinary use, they will disappear when photographed for reproduction. The maps may be obtained from Messrs. Oliver and Boyd, Tweedale Court, Edinburgh, at a cost which runs from $£ 13 s$. a hundred to $£ 22 s$. a thousand for the all black, and $£ 111 s$. 6d. a hundred to $£ 3$ a thousand for the black and blue.

\section{Libraries and Gardening}

A Catalogue of books on gardening, poultry and bees has recently been issued by the Leicester Municipal Libraries. Its contents are illuminating, and show that the gardening public is beginning to take an interest in the scientific aspects of their hobby, craft or vocation. Such volumes as Dr. Keen's "Physical Properties of the Soil", Bourcart's "Insecticides, Fungicides and Weed-Killers", Dr. Kenneth Smith's "Text Book of Agrisultural Entomology" and many others of proved scientific worth show that the modern gardener is alive to the need of moving with the times. More than fifty volumes are included in the section on garden planning, and the kitchen gardener and floriculturist are amply supplied with books. The sections on poultry-keeping and bee-keeping are good, but do not give evidence of such scientific and artistic progress as characterises the volumes on gardening.

\section{North American Birds of Prey}

CoNTINUING its series of reproductions of paintings of birds in North America, the National Geographic Magazine for July illustrates and describes the eagles, hawks and vultures. The descriptive text is by Alexander Wetmore, assistant secretary of the Smithsonian Institution; and the coloured pictures, 28 in number, by Major Allan Brooks, if inclined to be a little hard in texture and colour, are the best American drawings we have seen since the death of Louis Agassiz Fuertes. The present article is the fifth of a series very useful and attractive to bird lovers; the first, including humming birds, swifts and goat-suckers, appeared in July, 1932, the second, with ibises, herons and flamingoes in October, 1932, the third, with crows, magpies and jays in January, 1933, the fourth with woodpeckers in April, 1933, and the sixth will be published at an early date.

\section{Copper-Steel Welding}

The issue of the Scientific American for September contains a short illustrated description of a large Detroit welding plant capable of effecting 2,000 welds of steel parts an hour. The parts are either screwed or tightly fitted together and the joint has a thin copper wire or a paste of copper applied to it. A trolley full of articles is sent through a long tube 